Kalpataru, Volume 6, Nomor 2, Desember 2020 (147-152)

\title{
PERPADUAN PENINGGALAN BENTUK AKULTURASI ARSITEKTUR DI KOTA PALEMBANG
}

\author{
Muhammad Reza Arviansyah \\ Program Studi Pendidikan Sejarah FKIP Universitas Sriwijaya \\ Email: mrezaarvian@gmail.com \\ Hudaidah \\ Program Studi Pendidikan Sejarah FKIP Universitas Sriwijaya
}

\begin{abstract}
ABSTRAK
Akulturasi merupakan proses yang menarik apabila dilihat dari sisi kebudayaan, yang mana percampuran antara satu bentuk kebudayaan dengan kebudayaan lain akan mengahasilkan sebuah perpaduan kebudayaan yang indah bila dilihat, kebudayaan merupakan hasil pemikiran manusia yang dituangkan dan diwariskan secara turun temurun dan bersifat statis yang dapat menyesuaikan terhadap perkembangan zaman. Contohnya perpaduan kebudayaan di Kota Palembang dapat dilihat pada beberapa bangunan yang ada di kota Palembang yakni Masjid Sultan Mahmud Badaruddin I Jayo Wikramo (Masjid Agung Palembang), Masjid Al Islam Muhammad Cheng Ho (Masjid Cheng Ho Palembang), dan Rumah Limas (Rumah Adat Sumatera Selatan). Yang mana masing-masing bangunan ini memiliki corak kebudayaan yang beragam dan tercampur menjadi sebuah perpaduan akulturasi seperti perpaduan kebudayaan dari melayu Palembang, Tiongkok, dan Arab Timur Tengah dalam bidang Arsitekturnya. Sehingga dapat dilihat bagaimana percampuran kebudayaan yang ada pada tiga bangunan yang akan dibahas. Maka dari itu penulis dalam tulisannya ini akan mengumpulkan data-data tertulis yang berhubungan dengan tema yang akan dikaji, sehingga diharapkan dapat menghasilkan informasi yang dapat bermanfaat bagi semua orang.
\end{abstract}

\section{Kata Kunci: Bentuk, Akulturasi, Kota Palembang}

\section{A. PENDAHULUAN}

Indonesia terkenal dengan negara yang terdiri dari berbagai macam suku, bahasa, agama, dan adat istiadat yang beragam. Ini semua adalah gambaran bahwa Indonesia merupakan negara yang majemuk. Adat istiadat merupakan salah satu contoh yang memiliki pengaruh dan bersifat mengikat bagi suatu masyarakat. Kebudayaan yang beraneka ragam ini merupakan warisan turun temurun, yang membentuk suatu kebudayaan daerah, dan nantinya kebudayaan daerah inilah yang membentuk suatu kebudayaan nasional dan menjadi ciri khas dari suatu bangsa. Kebudayaan daerah inilah yang nantinya akan menonjolkan berbagai aspek dalam kehidupan masyarakat yang masing-masing daerah memiliki kebudayaan yang berbeda satu sama lain (Hikmawati, 2017).

Manusia merupakan makhluk sosial, makhluk sosial disini berarti sebuah makhluk yang membutuhkan orang lain di dalam hidupnya baik itu untuk berkomunikasi maupun berinteraksi dalam kegiatan sosial sehari-hari.
Dilihat ketika melakukan komunikasi dan memposisikan diri ketika sedang berinteraksi tentunya itu sangat dipengaruhi oleh kebudayaan yang telah menjadi kebiasaan dalam kehidupan manusia. Secara alamiah setiap orang pastinya telah mempelajari bagaimana cara ketika ingin menunjukan tingkah laku berdasarkan aturan-aturan yang berlaku dan norma-norma yang mengikat di dalamnya. Ini berarti menunjukan bahwa semua masyarakat tentunya memiliki karakter yang berbeda antara satu sama lain (Indra Dewi, 2013).

Dalam sebuah keberagaman disuatu masyarakat, tidak luput dengan tradisi-tradisi lokal yang ada dan telah hidup serta berkembang mengikuti keadaan masyarakat itu sendiri dan mengikuti perubahan zaman yang mana ketika mereka melakukan interaksi sosial dengan cara saling berkomunikasi serta saling beradaptasi terhadap lingkungan sekitar. Proses masuknya keberagaman kebudayaan yang ada di Indonesia juga tidak akan pernah lepas dari hal akulturasi, sehingga apapun jenis 
dan dari mana asalnya suatu kebudayaan itu dapat dengan mudah untuk diterima oleh masyarakat. Juga dengan mayoritas agama muslim yang ada di Indonesia dengan ajaran tidak boleh ada paksaan dalam suatu hal apapun itu menjadikan proses penyebaran suatu kebudayaan tanpa melalui adanya suatu kekerasan dan permusuhan, namun melalui cara perdamaian serta penyesuaian terlebih dahulu. Saling beradaptasi antara budaya lokal dan budaya luar yang masuk sehingga nantinya dapat lahir suatu kebudayaan baru yang tidak meninggalkan bentuk asli dari dua kebudayaan yang telah membaur tersebut (Arifai, 2018).

Semua yang telah diajarkan selama ini mengenai kebudayaan telah membentuk keyakinan yang mengatakan bahwa kebudayaan itu merupakan petunjuk arah yang telah berperan seperti kompas dan mata angin di dalam perjalanan hidup kita sebagai manusia yang memiliki peran mempengaruhi dalam tingkah laku hidup kita. Yang berarti kebudayaan ini mencakup menyeluruh terhadap semua orang sehingga dapat dipelajari oleh siapapun sebagai anggota dari masyarakat. Pola kehidupan prilaku yang terdiri dari segala hal mengenai cara berpikir, bergerak, dan bertindak merupakan segala sesuatu hal yang menyusun suatu kebudayaan. Baik itu berupa tujuh buah unsur yang membangun kebudayaan (Arifai, 2018).

Di dalam sebuah ruang lingkup budaya lokal tentu terbatas karena adanya wilayah geografis dan garis wilayah yang membatasi suatu pergerakan dari sebuah kelompok masyarakat. Seperti contoh budaya pada masyarakat Inggris tentunya berbeda dengan budaya pada masyarakat kita, begitu pula budaya pada masyarakat di pulau Sumatera tentunya berbeda dengan budaya pada masyarakat pulau Kalimantan, dan pada budaya masyarakat Palembang dengan budaya masyarakat Banjarmasin tentunya juga berbeda. Walaupun masih ada kemungkinan dapat ditemukannya berbagai perilaku yang sama di dalam kelompok masyarakat daerah yang berbeda. Hal ini dapat terjadi karena adanya proses percampuran kebudayaan baik itu melalui perkawinan maupun secara tidak sengaja. Dari pengertian secara umum mengenai kebudayaan dapat kita pahami jika budaya ini adalah hal yang penting dan sangat berhubungan dengan hasil olah pikiran dan tingkah laku manusia di dalam kehidupan bermasyarakat dan telah ada sejak dahulu yang diwariskan secara turun temurun (Junaid, 2013).

\section{B. METODE PENELITIAN}

Di dalam penulisan, yang akan dibahas adalah mengenai perpaduan akulturasi yang terdapat di Kota Palembang, yang dijadikan objek untuk penulisan ini adalah teks yang memuat atau mengandung serta terdapat gagasan tertentu di dalamnya. Selain pada objek penelitian, jenis data yang digunakan dalam penulisan yaitu data kualitatif. Data kualitatif inilah yang nantinya kemudian akan menjadi data deskriptif yang berisikan datadata tertulis dan saling berkaitan diantara satu sama lain (Rasimin, 2018). Maka apabila dilihat dari jenis data dan tema penelitian yang akan dikaji, berdasarkan itu jenis penelitian ini merupakan penelitian pustaka (library research). Penelitian ini pun menggunakan metode literatur yang mana dalam proses pengumpulan data dilakukan dengan cara mengumpulkan berbagai sumber data tertulis yang didapat dari studi pustaka jurnal, skripsi, buku dan juga sumber lainnya yang didapat dari internet yang bersifat relevan.

\section{HASIL DAN PEMBAHASAN}

Dalam perkembangannya pada pusatpusat peradaban di dunia telah banyak ditunjukkan bahwa awal mula munculnya itu juga dipengaruhi oleh peran dari sebuah sungai. Ambil saja contoh pada peradaban terkenal di dunia, yaitu pada masa peradaban Mesir Kuno yang mana adanya peran dari sungai Nil dan lembah yang berada disekitar. Kemudian pada peradaban India Kuno yang didukung oleh adanya sungai Gangga dan sungai Tigris. Sungai Tigris dan sungai Eufrat yang mempengaruhi dari perkembangan peradaban masyarakat di daerah Mesopotamia. Sama halnya dengan salah satu sungai yang ada di Indonesia, yakni sungai Musi yang mempengaruhi daripada perkembangan kerajaan bercorak Budha sekaligus maritim 
Sriwijaya hingga pada masa perkembangan kerajaan Islam Kesultanan Palembang Darussalam. Terlihat dari beberapa contoh di atas bahwa ada peran yang besar dari posisi letak geografis suatu wilayah yang mengakibatkan sebuah pembentukan dan sebagai aset paling penting bagi pendirian sebuah peradaban manusia (Farida et al., 2019).

Salah satu daerah di Indonesia yang dapat dibilang memiliki sejarah dan budaya yang panjang adalah pada daerah Palembang, mulai dari awal munculnya kerajaan maritim pertama dan terbesar di Indonesia yakni Kerajaan Sriwijaya, kemudian hingga berdirinya Kesultanan Palembang Darussalam. Banyak bukti yang berhasil ditemukan salah satunya merupakan Prasasti Kedukan Bukit yang merupakan prasasti tertua berisi tentang pendirian Kerajaan Sriwijaya dan dikatakan juga sebagai akte dari Kota Palembang. Namun belum dipastikan bahwa nama Palembang ini sendiri digunakan bersamaan dengan pendirian kerajaan Sriwijaya ataupun sesudah runtuhnya kekuasaan maritim dari Kerajaan Sriwijaya (Sustianingsih et al., 2019).

Cerita sejarah dari Palembang yang cukup panjang ini juga merupakan faktor penting, terutama apabila dilihat memang potensi terbesar dari wilayah Palembang ini terletak pada sektor ekonomi dengan penduduk yang menyebar secara menyeluruh dan banyak terdiri dari beberapa suku atau marga yang berbeda. Terdapat banyak penduduk yang tinggal pada pusat ibukota, pinggiran kota, maupun pada pulau Bangka Belitung. Namun terdapat perbedaan antara penduduk yang tinggal di pusat ibukota yakni Palembang dengan penduduk yang tinggal pada daerah pedalaman, yang mana penduduk di pusat ibukota ini telah memiliki banyak percampuran sehingga terdiri dari berbagai rumpun etnis yang berbeda. Sedangkan pada penduduk di daerah pedalaman itu merupakan penduduk asli daerah Palembang (Nawiyanto \& Endrayadi, 2016). Maka dari itu akan diambil tiga peninggalan sejarah yang ada di Kota Palembang yang mengalami akulturasi atau percampuran antar kebudayaan dalam bidang arsitekturnya.

\section{Masjid Agung Palembang}

Masjid Sultan Mahmud Badaruddin I Jayo Wikramo, atau yang dulunya lebih dikenal dengan Masjid Agung Palembang adalah salah satu peninggalan dari masa pemerintahan kekuasaan Kesultanan Palembang Darussalam, tentunya masjid pada setiap daerah di Indonesia ini memiliki banyak perbedaan dan ciri masing-masing jika dilihat dari segi bangunan atau arsitekturnya. Dalam hal ini bangunan atau arsitektur dulu kala sering mengalami proses percampuran kebudayaan, baik itu kebudayaan lokal dengan lokal, dan lokal dengan luar. Akulturasi kebudayaan ini melekat pada wujud budaya yang bersifat monumental, seperti yang ada pada Masjid Sultan Mahmud Badaruddin I Jayo Wikramo terdapat unsur percampuran kebudayaan lokal, Eropa, maupun Arab (Susandi, 2010).

Masjid SMB I ini terletak di pusat kota Palembang yang sekaligus juga berada di daerah 0 KM Palembang. Masjid ini didirikan oleh Sultan Mahmud Badaruddin I pada tahun 1738 dan selesai dengan memakan waktu 10 tahun lamanya. Dari kondisi penampakan bangunan ini dapat terlihat jelas perpaduan antara budaya Timur dan Barat. Pada bagian atap dari masjid berbentuk model atap limas kemudian ada daun simbar yang berfungsi sebagai penghias sebanyak 13 buah yang melengkung menyerupai tanduk kambing. Bentuk ini seperti corak pada atap kelenteng dan bangunan arsitektur Cina lainnya. Kemudian pada Masjid Agung ini juga terdapat ukiran-ukiran kaligrafi khas Arab yang dipadukan dengan budaya lokal menghiasi pada pintu, tembok, maupun jendela yang terdapat pada sekeliling masjid. Pada bagian mimbar imam dan pintu masjid juga dihiasi dengan ukiran kaligrafi yang tak kalah indahnya. Di teras masjid ini juga berbentuk layaknya seni arsitektur klasik Yunani yang banyak ditemui pada bangunan bercorak India pada awal abad 20 (Susandi, 2010).

Di Masjid Agung Palembang terbagi atas 3 kelompok ornamen yakni kelompok ornamen bentuk geometris, kelompok ornamen bentuk kaligrafi, dan kelompok ornamen bentuk tumbuhan. Jika dilihat pada kelompok bentuk geometris disini sering dijumpai di bidang 
tunggal yang dipadukan dengan ukiran seni kaligrafi Arab dan bentuk motif tumbuhan yang dapat kita lihat pada pagar, gerbang, atap, ventilasi. Sedangkan jika hanya ingin melihat ukiran kaligrafi Arab itu terdapat pada hampir seluruh bangunan masjid yang sarat akan huruf Al-Qur'an. Pada bangunan masjid berbentuk tumbuhan ini sering dijumpai bentuk akar, daun, dan buah yang merupakan penyerapan dari bentuk tumbuhan yang dapat dilihat pada pintu masuk, mimbar masjid, kursi mimbar, dan pembatas untuk shalat (llhaq, 2016).

\section{Masjid Cheng Ho}

Masjid Al Islam Muhammad Cheng Ho Sriwijaya, atau yang lebih dikenal dengan nama Masjid Cheng Ho adalah masjid yang didirikan dengan menggunakan beberapa campuran kebudayaan. Masjid ini terletak di Kota Palembang, tepatnya berada di jalan yang bersebrangan langsung dengan komplek olahraga Jakabaring Sport City. Pada warna fisik di bangunan masjid ini menggunakan dua warna dominan yakni warna merah dan hijau yang diusulkan oleh para warga keturunan Tionghoa di Palembang. Yang terlihat dengan jelas bahwa memang masjid ini mengusung percampuran kebudayaan antara corak lokal, Islam, dan Cina. Jika dilihat secara langsung juga memang nampak perbedaan masjid ini dengan masjid lain pada umumnya, baik dari bentuk bangunan, warna, dan lainnya. Memang terlihat jelas budaya Cina yang mempengaruhi bentuk masjid (Narhadi, 2019).

Dilihat secara menyeluruh, pada bentuk bangunan masjid ini didominasi dengan warna merah dan warnah hijau yang sangat dominan. Pada pintu masuk maupun atap masjid dapat dijumpai ornamen bangunan Cina, yang mana memiliki bentuk lengkung dan warna kuning yang menyerupai tempat peribadatan dan bangunan khas Cina. Penggunaan kaligrafi ukiran Arab juga dapat ditemui pada jendela maupun di atas mimbar. Penggunaan tiang pada bangunan dalam masjid juga berwarna merah dengan ukiran kaligrafi disekitarnya, dapat dilihat bahwa ini merupakan bentuk percampuran budaya sekaligus bentuk tiang masjid ini menyerupai bentuk pada tiang di bagian dalam klenteng (Narhadi, 2019).
Penggunaan ornamen pada Masjid Cheng $\mathrm{Ho}$ ini tidak semata-mata hanya didominasi oleh bangunan arsitektur khas Tiongkok, namun di masjid ini juga terdapat bangunan arsitektur Palembang yaitu adanya tanduk kambing pada bagian atas bangunan. Wujud akulturasi yang dapat dilihat juga menggunakan menara masjid yang menyerupai bentuk pagoda meniru pada bentuk klentengklenteng Cina. Masjid Cheng Ho ini dibuat khusus untuk menghargai perjuangan dari penyebaran agama Islam terkhususnya penyebaran Islam di Kota Palembang yang dilakukan oleh Laksamana Cheng Ho dan para muslim Tiongkok lainnya. Sehingga memang corak bangunan masjid lebih ditekankan antara perpaduan 3 corak perpaduan budaya Melayu Palembang, Tiongkok, dan Arab (Pulungan, 2017).

Selain digunakan sebagai tempat beribadah, masjid Cheng Ho ini juga digunakan sebagai pusat penyebaran Islam khususnya bagi masyarakat mualaf Tionghoa. Kegiatan di dalam masjid ini seperti pengajian, tadarus, sholat, kegiatan amal, bakti sosial, dan sosialisasi kemasyarakatan yang kerap dilakukan. Maka eksistensi Masjid Cheng Ho ini bukan hanya sekedar sebagai tempat peribadatan muslim asli Indonesia saja namun juga menjadi tempat ibadah khas bagi orang muslim keturunan Tionghoa dan sebagai icon monumen Islam Melayu yang ada di Palembang (Pulungan, 2017).

\section{Rumah Limas}

Rumah Limas merupakan rumah adat yang berasal dari provinsi Sumatera Selatan, peninggalan dari zaman Kesultanan Palembang Darussalam. Rumah ini memiliki sebuah makna penting bagi masyarakat khususnya masyarakat Kota Palembang. Tidak hanya sebagai rumah atau hiasan belaka, namun semua hal di rumah ini direncanakan dan dibangun dengan sedemikian rupa sehingga dalam setiap sisinya rumah ini memiliki detail yang mempunyai arti tersendiri. Sebelum proses awal pembangunan rumah ini, ada upacara-upacara khusus yang memang harus dilakukan terlebih dahulu. Juga dalam proses pemilihan bahan awal seperti kayu yang akan 
digunakan juga sangat penting untuk diperhatikan (Pratama, 2019).

Rumah Limas memiliki bentuk khas yang terletak pada bagian atapnya. Kemudian pada bagian tubuh rumah terbuat dari papan dan ketinggian di dalam rumah dibuat bertingkat sesuai dengan ketentuan yang telah diatur sedemikian rupa. Rumah ini memiliki corak ukiran berbentuk flora (tumbuhan) dan ukiran kaligrafi huruf Arab. Dengan memiliki bentuk atap meninggi keatas karena adanya pengaruh dari agama Hindu-Budha, namun atap tidak terlalu dibuat bertingkat karena juga memperhatikan unsur Islam. Unsur Islam dapat dilihat pada motif corak dari flora ataupun kaligrafi yang merupakan ciri khas dari Islam. Ukiran-ukiran ini dapat dilihat disekeliling rumah. Ukiran flora (tumbuhan) ini juga diadopsi menjadi ukiran khas dari Palembang. Untuk pengaruh Cina juga dapat dilihat pada beberapa ornamen yang terdapat di dalam rumah seperti guci dan benda rumah tangga lain yang memiliki warna merah keemasan. Konon pengukir awal dari pembangunan rumah limas ini dulu juga merupakan bangsa Cina yang datang ke Nusantara, diperkirakan datang pada abad ke16 M (Pratama, 2019).

\section{SIMPULAN}

Dalam sejarah, Kota Palembang memiliki beberapa kerajaan besar pada masanya, baik itu kerajaan yang bercorak agama Budha yakni Kerajaan Sriwijaya maupun kerajaan yang bercorak agama Islam yakni Kesultanan Palembang Darussalam. Belum lagi nanti ada campur tangan oleh pemerintahan kolonial Belanda dan Inggris yang sempat memonopoli perdagangan, mengeksploitasi sumber daya manusia dan menguasai penuh pemerintahan wilayah Kota Palembang. Dalam perkembangannya tentu banyak keberagaman penduduk yang ada, karena Palembang dengan Sungai Musinya merupakan pusat perdagangan dan pelayaran. Banyak pedagang yang singgah ke sini dan tentunya mereka tak hanya singgah semata, pasti ada penyebaran yang mereka lakukan baik itu penyebaran agama maupun penyebaran kebudayaan. Peninggalan akulturasi di Kota Palembang dapat kita lihat pada tiga buah bangunan bersejarah dan telah menjadi monumen atau sebagai icon di Kota Palembang. Jika ditelusuri juga pada perkembangannya Kota Palembang juga menjadi salah satu kota tertua yang ada di Indonesia. Palembang dulunya terkenal dari mulai Kerajaan Sriwijaya hingga Kesultanan Palembang Darussalam ini memang identik dengan ekonomi perdagangan yang mana dengan menggunakan jalur laut. Tidak heran bahwa banyaknya pedagang dari luar yang singgah dan menetap disini menjadikan keberagaman penduduk yang ada di Kota Palembang, keberagaman inilah nantinya menjadi sebuah perpaduan antara penduduk asli dan penduduk pendatang. Terciptanya akulturasi kebudayaan merupakan hal yang wajar, wujud akulturasi itu dapat dilihat pada Masjid Sultan Mahmud Badaruddin I Jayo Wikramo (Masjid Agung Palembang), Masjid Al Islam Muhammad Cheng Ho (Masjid Cheng Ho Palembang), dan Rumah Limas (rumah adat tradisional).

\section{DAFTAR PUSTAKA}

Arifai, A. (2018). Akulturasi Islam Dan Budaya Lokal. Journal of Chemical Information and Modeling, 53(9), 1689-1699. http://jurnal.radenfatah.ac.id/index.php/A s-Shuffah/article/view/4855

Farida, I., Rochmiatun, E., \& Kalsum, N. U. (2019). Peran Sungai Musi dalam Perkembangan Peradaban Islam di Palembang: Dari Masa Kesultanan sampai Hindia-Belanda. JUSPI (Jurnal Sejarah Peradaban Islam), 3(1), 50. https://doi.org/10.30829/juspi.v3i1.4079

Hikmawati, E. (2017). Makna Simbol dalam Aesan Gede dan Pak Sangkong Pakaian Adat Pernikahan Palembang. Intelektualita, 06, 1-12.

Ilhaq, M. (2016). Bentuk dan Penempatan Ornamen pada Masjid Agung Palembang. Ekspresi Seni, 18, 180-193.

Indra Dewi, S. (2013). Culture Shock dan Akulturasi dalam Lingkungan Budaya 
Belanda. Jurnal Reformasi, 3(9), 42-52. /citations?view_op=view_citation\&contin ue $=/$ scholar\%3Fhl\%3Dpt-

BR\%26as_sdt\%3D0,5\%26scilib\%3D1\&c itilm=1\&citation_for_view=wSOxi2wAAA $A J: 20 s O g N Q 5 q M E C \& h l=p t-B R \& o i=p$

Junaid, H. (2013). Kajian Kritis Akulturasi Islam Dengan Budaya Lokal. 1(April), 56-73.

Narhadi, J. S. (2019). Kajian Bentuk, Fasad, Dan Ruang Dalam Pada Masjid Cheng Ho Palembang. Jurnal Arsitektur ZONASI, $\quad 2(3), \quad 183$. https://doi.org/10.17509/jaz.v2i3.19261

Nawiyanto, \& Endrayadi, E. (2016). Kesultanan Palembang Darussalam sejarah dan warisan budayanya.

https://repository.unej.ac.id/bitstream/ha ndle/123456789/75333/Nawiyanto\%2C

Eko CE_Buku_Kesultanan

Palembang_\%28F. IImu Budaya\%29.pdf?sequence $=1$

Pratama, Y. (2019). Rumah limas: Refleksi sejarah akulturasi kebudayaan masyarakat sumatera selatan. JHCJ: Jambura History and Culture Journal, 1(1).

https://ejurnal.ung.ac.id/index.php/jhcj/art icle/download/2529/1516

Pulungan, J. S. (2017). DINAMIKA KEBUDAYAAN ISLAM MELAYU DI NUSANTARA (Masjid Cheng Ho di Palembang Akulturasi Cina dan Melayu Palembang). 1-18.

Rasimin. (2018). Metodologi Penelitian Pendekatan Praktis Kualitatif (pp. 1-37). http://e-

repository.perpus.iainsalatiga.ac.id/4494/ 1/METODOLOGI PENELITIAN Pendekatan Praktis Kualitatif.pdf

Susandi, A. (2010). Akulturasi budaya pada arsitektur masjid agung palembang.
Sustianingsih, I. M., Yati, R. M., \& Iskandar, Y. (2019). Peran Sultan Mahmud Badaruddin I Dalam Pembangunan Infrastruktur Di Kota Palembang (17241758). TAMADDUN: Jurnal Kebudayaan Dan Sastra Islam, 19(1), 49-62. https://doi.org/10.19109/tamaddun.v19i1. 3399 


\section{KETENTUAN PENULISAN ARTIKEL JURNAL KALPATARU}

1. Naskah berbahasa Indonesia yang disempurnakan bertemakan kesejarah yang meliputi hasil penelitian sejarah, pengajaran sejarah dan penelitian kebudayaan.

2. Naskah harus asli dan belum pernah dimuat dalam media lain. Naskah dapat berupa hasil penelitian/artikel kajian konseptual yang ditulis oleh perorangan dan atau kelompok.

3. Naskah ditulis dengan cara-cara yang sesuai dengan ketentuan penulisan artikel ilmiah menggunakan bahasa Indonesia yang baku, berupa ketikan, beserta soft file dalam CD-RW atau dengan mengirimkan email pada redaksi jurnal Kalpataru dengan alamat jurnalkalpatarusejarah@gmail.com, spasi tunggal, jenis huruf arial narrow ukuran 12, dengan panjang naskah antara 8-15 halaman pada kertas A4.

4. Artikel hasil penelitian memuat:

JUDUL

Nama Penulis

Abstrak

\section{A. PENDAHULUAN}

B. METODE PENELITIAN

C. HASIL DAN PEMBAHASAN

D. SIMPULAN

DAFTAR PUSTAKA
: XXX (HURUF KAPITAL)

: (disertai jabatan, institusi, dan email)

: (Bahasa Indonesia yang memuat 100-200 kata diikuti kata kunci, dengan jenis huruf arrial narrow dan ukuran huruf 11 serta dicetak miring).

: (memuat latar belakang masalah, tinjauan pustaka secara ringkas, masalah penelitian, dan tujuan penelitian).

5. Artikel Kajian Konseptual memuat:

JUDUL

Nama Penulis

Abstrak

\section{PENDAHULUAN}

Sub Judul

Simpulan

DAFTAR PUSTAKA

\section{: XXX (HURUF KAPITAL)}

: (disertai jabatan, institusi, dan email)

: (Bahasa Indonesia yang memuat 100-200 kata diikuti kata kunci, dengan jenis huruf arrial narrow dan ukuran huruf 11 serta dicetak miring.

: (memuat latar belakang masalah, tinjauan pustaka secara ringkas, masalah penelitian, dan tujuan penelitian).

: Sesuai dengan kebutuhan (tanpa numbering).

: (berisi simpulan dan saran).

6. Referensi sumber dalam teks artikel ditulis dengan menggunakan side note, contoh (Jalaludin, 1991:79); sementara penulisan daftar pustaka disusun dengan ketentuan. Nama pengarang. Tahun terbit. Judul (dicetak miring). Kota terbit: Nama Penerbit. Contoh: Koentjaraningrat. 2010. Manusia dan Kebudayaan di Indonesia. Jakarta: Djambatan. Daftar pustaka hanya memuat pustaka/sumber yang dirujuk dalam uraian dan disusun menurut abjad tanpa nomor urut.

7. Naskah yang dimuat akan disunting kembali oleh redaksi tanpa mengubah isinya.

8. Naskah yang ditolak (tidak bisa dimuat) akan dikirim kembali ke penulis dengan pemberitahuan tertulis dari redaksi atau melalui email.

9. Penulis yang naskahnya dimuat akan mendapat 1 (satu) majalah nomor yang bersangkutan.

10. Kontak person: Muhamad Idris (081271498618); Eva Dina Chairunisa (082281267851); Jeki Sepriady (085269261780). 